\title{
Finding the Optimum Chloride-Based Chemistry for Chemical Vapor Deposition of $\mathrm{SiC}$
}

Milan Yazdanfar, Örjan Danielsson, Olle Kordina, Erik Janzén and Henrik Pedersen

\author{
Linköping University Post Print
}

Tweet

N.B.: When citing this work, cite the original article.

Original Publication:

Milan Yazdanfar, Örjan Danielsson, Olle Kordina, Erik Janzén and Henrik Pedersen, Finding the Optimum Chloride-Based Chemistry for Chemical Vapor Deposition of SiC, 2014, ECS Journal of Solid State Science and Technology, 3(10), P320-P323.

http://dx.doi.org/10.1149/2.0111410jss

Copyright: Electrochemical Society

http://www.electrochem.org/

Postprint available at: Linköping University Electronic Press

http://urn.kb.se/resolve?urn=urn:nbn:se:liu:diva-111074 


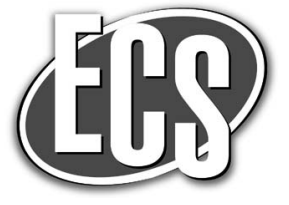

\title{
Finding the Optimum Chloride-Based Chemistry for Chemical Vapor Deposition of $\mathrm{SiC}$
}

\author{
Milan Yazdanfar, ${ }^{\mathrm{z}}$ Örjan Danielsson, Olle Kordina, Erik Janzén, and Henrik Pedersen ${ }^{\mathrm{z}}$ \\ Department of Physics, Chemistry and Biology, Linköping University, SE-581 83 Linköping, Sweden
}

\begin{abstract}
Chemical vapor deposition of silicon carbide with a chloride-based chemistry can be done using several different silicon and carbon precursors. Here, we present a comparative study of $\mathrm{SiCl}_{4}, \mathrm{SiHCl}_{3}, \mathrm{SiH}_{4}+\mathrm{HCl}, \mathrm{C}_{3} \mathrm{H}_{8}, \mathrm{C}_{2} \mathrm{H}_{4}$ and $\mathrm{CH}_{4}$ in an attempt to find the optimal precursor combination. We find that while the chlorinated silanes $\mathrm{SiCl}_{4}$ and especially $\mathrm{SiHCl}_{3}$ give higher growth rate than natural silane and $\mathrm{HCl}, \mathrm{SiH}_{4}+\mathrm{HCl}$ gives better morphology at $\mathrm{C} / \mathrm{Si}$ around 1 and $\mathrm{SiCl}_{4}$ gives the best morphology at low $\mathrm{C} / \mathrm{Si}$. Our study shows no effect on doping incorporation with precursor chemistry. We suggest that these results can be explained by the number of reaction steps in the gas phase chemical reaction mechanisms for producing $\mathrm{SiCl}_{2}$, which is the most important $\mathrm{Si}$ species, and by formation of organosilicons in the gas phase. As carbon precursor, $\mathrm{C}_{3} \mathrm{H}_{8}$ or $\mathrm{C}_{2} \mathrm{H}_{4}$ are more or less equal in performance with a slight advantage for $\mathrm{C}_{3} \mathrm{H}_{8}, \mathrm{CH}_{4}$ is however not a carbon precursor that should be used unless extraordinary growth conditions are needed.

(C) The Author(s) 2014. Published by ECS. This is an open access article distributed under the terms of the Creative Commons Attribution 4.0 License (CC BY, http://creativecommons.org/licenses/by/4.0/), which permits unrestricted reuse of the work in any medium, provided the original work is properly cited. [DOI: 10.1149/2.0111410jss] All rights reserved.
\end{abstract}

Manuscript submitted July 2, 2014; revised manuscript received July 25, 2014. Published August 5, 2014.

For the last, approximately ten years, chloride-based chemistry has been studied for chemical vapor deposition (CVD) of electronic grade $\mathrm{SiC}^{1}{ }^{1}$ The addition of $\mathrm{Cl}$ to the gas mixture circumvents condensation of silicon droplets above the substrate since the stronger $\mathrm{Si}-\mathrm{Cl}$ bond $(400 \mathrm{~kJ} / \mathrm{mol} \text { or } 4.15 \mathrm{eV})^{2}$ prevents $\mathrm{Si}-\mathrm{Si}$ bonds $(226 \mathrm{~kJ} / \mathrm{mol}$ or $2.34 \mathrm{eV})^{2}$ to form. This allows a higher precursor concentration in the CVD gas mixture which enables higher growth rates of epitaxial $\mathrm{SiC}$ layers; growth rates exceeding $100 \mu \mathrm{m} / \mathrm{h}$ are common, compared to the $5-10 \mu \mathrm{m} / \mathrm{h}$ usually obtained for the standard, non-chlorinated chemistry based on silane $\left(\mathrm{SiH}_{4}\right)$ and small hydrocarbons like ethylene $\left(\mathrm{C}_{2} \mathrm{H}_{4}\right)$ or propane $\left(\mathrm{C}_{3} \mathrm{H}_{8}\right)$. Cl-based CVD chemistry is therefore seen as an enabler of $\mathrm{SiC}$ power device technology ${ }^{1}$, where approximately $100 \mu \mathrm{m}$ thick, low doped $\left(10^{14} \mathrm{~cm}^{-3}\right)$, epitaxial layers are required for devices capable of blocking voltages on the order of $10 \mathrm{kV}$.

Addition of $\mathrm{Cl}$ can be done either through the addition of $\mathrm{HCl}$ to the standard precursors, by using a chlorinated silane molecule $\left(\mathrm{SiH}_{\mathrm{x}} \mathrm{Cl}_{\mathrm{y}}\right)$ instead of $\mathrm{SiH}_{4}$, by using a chlorinated hydrocarbon $\left(\mathrm{CH}_{\mathrm{x}} \mathrm{Cl}_{\mathrm{y}}\right)$ instead of $\mathrm{C}_{3} \mathrm{H}_{8} / \mathrm{C}_{2} \mathrm{H}_{4}$ or by using a single molecule $\left(\mathrm{SiH}_{\mathrm{x}} \mathrm{C}_{\mathrm{y}} \mathrm{Cl}_{\mathrm{z}}\right)$. All these approaches have been reported to be successful and capable of growth rates exceeding $100 \mu \mathrm{m} / \mathrm{h} .{ }^{1}$ However, the optimal precursor for $\mathrm{Cl}$ based CVD of $\mathrm{SiC}$ is still not identified, despite ten years of research on Cl-based CVD chemistry. The single molecule approach has been successful, ${ }^{3}$ but the inherent locked $\mathrm{C} / \mathrm{Si}$ ratio hinders an efficient control of the doping incorporation ${ }^{4}$ in $\mathrm{SiC}$. Thermochemical studies suggests that the use of $\mathrm{CH}_{\mathrm{x}} \mathrm{Cl}_{\mathrm{y}}$ is not likely an optimal route since the $\mathrm{C}-\mathrm{Cl}$ bond is found to break, allowing $\mathrm{Si}-\mathrm{Cl}$ bonds to form. ${ }^{5}$ Thus the $\mathrm{CH}_{\mathrm{x}} \mathrm{Cl}_{\mathrm{y}}$ approach is probably a chemical detour. There have been attempts to compare data from various groups ${ }^{1,6}$ but these comparisons are hampered by the fact that the data are acquired in different CVD reactors in different labs. In this paper we make direct comparisons, in one CVD reactor, between growth chemistries from all combinations of one $\mathrm{Si}$ precursor and one $\mathrm{C}$ precursor from $\mathrm{SiCl}_{4}, \mathrm{SiHCl}_{3}$, $\mathrm{SiH}_{4}+\mathrm{HCl}, \mathrm{C}_{3} \mathrm{H}_{8}, \mathrm{C}_{2} \mathrm{H}_{4}, \mathrm{CH}_{4}$, as summarized in Figure 1. The inclusion of $\mathrm{CH}_{4}$ might be surprising since it is commonly regarded not to be a suitable precursor for electronic grade $\mathrm{SiC}$; however, we have recently shown that methane can be used albeit only with a very precise control of the growth chemistry. ${ }^{7}$

\section{Experimental}

Growth experiments were done in a horizontal hot wall chemical vapor deposition (CVD) reactor without rotation of the substrate. ${ }^{8}$ For all experiments, the growth pressure and growth time were kept constant at $100 \mathrm{mbar}$ and $15 \mathrm{~min}$, respectively. The growth temperature

zE-mail: milya@ifm.liu.se; henke@ifm.liu.se was $1575-1625^{\circ} \mathrm{C}$ and $50 \mathrm{l} / \mathrm{min}$ of palladium membrane purified $\mathrm{H}_{2}$ was used as carrier gas. All substrates in this work were approximately $15 \times 15 \mathrm{~mm}^{2}$ samples cut from one chemo-mechanically polished 6 inch $4 \mathrm{H}-\mathrm{SiC}$ wafer with $4^{\circ}$ off-cut toward the [11-20] direction. All growth experiments were done on the $\mathrm{Si}$-face of the substrate.

An $\mathrm{HCl}$ flow of $300 \mathrm{~mL} / \mathrm{min}$ was added to the $\mathrm{H}_{2}$ flow at a process temperature of $1175^{\circ} \mathrm{C}$ for surface preparation. The $\mathrm{HCl}$ flow was kept constant during the whole temperature ramp-up, until the growth temperature was reached, and then another 12 min for etching at the growth temperature. ${ }^{9}$ No intentional dopants were added in this study.

Silane $\left(\mathrm{SiH}_{4}\right)$, trichlorosilane $\left(\mathrm{SiHCl}_{3}\right)$ and tetrachlorosilane $\left(\mathrm{SiCl}_{4}\right)$ were used as silicon precursors, and propane $\left(\mathrm{C}_{3} \mathrm{H}_{8}\right)$, ethylene $\left(\mathrm{C}_{2} \mathrm{H}_{4}\right)$ and methane $\left(\mathrm{CH}_{4}\right)$ as carbon precursors, in nine different combinations (Figure 1 ). A Si/ $\mathrm{H}_{2}$ ratio of $0.25 \%$ was used for all experiments. The $\mathrm{Cl} / \mathrm{Si}$ was equal to 4 in all experiments, which was achieved by adding $\mathrm{HCl}$ to the flow in the cases where $\mathrm{SiH}_{4}$ and $\mathrm{SiHCl}_{3}$ were used as Si-precursors. The $\mathrm{C} / \mathrm{Si}$ ratio was varied between 0.6 and 1.0 by changing the carbon precursor flow.

The thickness of the epitaxial layers was measured using Fourier transform reflectance (FTIR) and the morphology of the epitaxial layers was studied by an optical microscope with Nomarski differential interference contrast, and in more detail by atomic force microscopy (AFM) in tapping mode on a $20 \times 20 \mu \mathrm{m}^{2}$ area at the center of the substrate and at two different areas close to the periphery, about $2 \mathrm{~mm}$ from the edge. The net carrier concentration of the grown epitaxial layers was determined from capacitance-voltage (CV) measurement using a mercury-probe. The material quality of the grown epitaxial layers was studied by low temperature photoluminescence (LTPL) at $2 \mathrm{~K}$ with a frequency doubled Argon ion laser at $244 \mathrm{~nm}$.

\section{Results and Discussion}

The growth chemistries were compared using three criteria: growth rate, surface roughness and net carrier concentration. The growth rate variation over the $15 \times 15 \mathrm{~mm}^{2}$ samples was around $1 \%$. The surface roughness is quantified by using the root mean square (RMS) value for the height variations measured on a $20 \times 20 \mu \mathrm{m}^{2}$ area in AFM. The net carrier concentration is here the background doping since no intentional dopants were added; all layers have a background doping in the low $10^{14} \mathrm{~cm}^{-3}$ range.

It was noted that when using chlorosilanes $\left(\mathrm{SiHCl}_{3}\right.$ and $\left.\mathrm{SiCl}_{4}\right)$ it was necessary to increase the temperature somewhat compared to the $\mathrm{SiH}_{4}+\mathrm{HCl}$ case in order to circumvent the formation of typical surface defects for growth on $4^{\circ}$ off axis cut $4 \mathrm{H}-\mathrm{SiC}$ substrates. Growth runs using $\mathrm{SiHCl}_{3}$ and $\mathrm{SiCl}_{4}$ were therefore done at $1625^{\circ} \mathrm{C}$ while the $\mathrm{SiH}_{4}$ based growth runs were done at $1575^{\circ} \mathrm{C}$ since using $\mathrm{SiH}_{4}+\mathrm{HCl}$ 


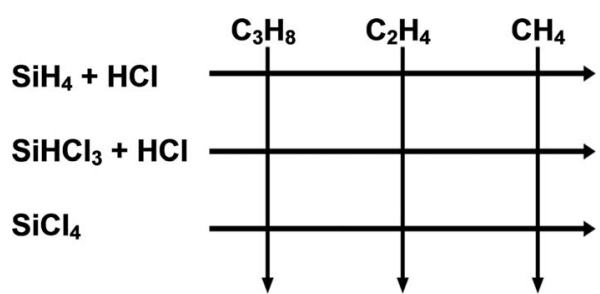

Figure 1. Summary of the precursor combinations in this study.

at $1625^{\circ} \mathrm{C}$ results in a step-bunched surface. This slight variation in temperature did not affect the growth rate for either of the silicon chemistries.

All grown epitaxial layers were studied by low temperature photo luminescence which showed that all samples were of high quality, low doped $4 \mathrm{H}-\mathrm{SiC}$. No correlation in the PL signal could be seen with different precursor chemistries.

It has been argued that for Cl-based chemistry, $\mathrm{C}_{2} \mathrm{H}_{2}$ and $\mathrm{SiCl}_{2}$ are the molecules contributing the most to the $\mathrm{SiC}$ growth. ${ }^{10,1}$ Depending on which precursors are used, the chemical reaction routes to forming these species may be different, which should influence the growth efficiency of the respective precursor combination.

Decomposition of $\mathrm{SiCl}_{4}$ takes place mainly through exchange of one chlorine atom at the time for one hydrogen atom through reactions with $\mathrm{H}_{2}$, producing $\mathrm{HCl}$, so that $\mathrm{SiCl}_{4} \rightarrow \mathrm{SiHCl}_{3} \rightarrow \mathrm{SiH}_{2} \mathrm{Cl}_{2} \rightarrow$ $\mathrm{SiH}_{3} \mathrm{Cl}^{11}$ The same route applies to $\mathrm{SiHCl}_{3}$ as precursor, albeit the first step is missing. If instead $\mathrm{SiH}_{4}$ is used, the reactions proceed in the opposite direction by first forming $\mathrm{SiH}_{2}+\mathrm{H}_{2}$, and then $\mathrm{SiH}_{2}$ $+\mathrm{HCl} \rightarrow \mathrm{SiH}_{3} \mathrm{Cl}$, which then turns into $\mathrm{SiH}_{2} \mathrm{Cl}_{2}$ and $\mathrm{SiHCl}_{3}$ via reactions with $\mathrm{HCl}$, producing $\mathrm{H}_{2}$. Since this route involves reactions with $\mathrm{HCl}$ (instead of $\mathrm{H}_{2}$ ), which has a much lower concentration than $\mathrm{H}_{2}$, it is expected that these reactions will be slower (even if the $\mathrm{Si}-\mathrm{H}$ bond is weaker $(323 \mathrm{~kJ} / \mathrm{mol} \text { or } 3.35 \mathrm{eV})^{2}$ than $\mathrm{Si}-\mathrm{Cl}$, and the reactions therefore would have lower activation energy). Regardless of silicon precursor, $\mathrm{SiCl}_{2}$ is mainly formed from either $\mathrm{SiHCl}_{3}$ or $\mathrm{SiH}_{2} \mathrm{Cl}_{2}$, by release of $\mathrm{HCl}$ and $\mathrm{H}_{2}$, respectively. Production of $\mathrm{SiCl}_{2}$ directly from $\mathrm{SiCl}_{4}$ by release of $\mathrm{Cl}_{2}$ is not likely due to the high symmetry of the $\mathrm{SiCl}_{4}$ molecule and the strong $\mathrm{Si}-\mathrm{Cl}$ bond. This means that from $\mathrm{SiH}_{4}$ there are four reaction steps to reach $\mathrm{SiCl}_{2}$, from $\mathrm{SiCl}_{4}$ there are two, and from $\mathrm{SiHCl}_{3}$ there is only one reaction step. Thus, $\mathrm{SiHCl}_{3}$ should be the most efficient precursor, and the $\mathrm{SiH}_{4}+\mathrm{HCl}$ combination the least efficient one. This reasoning is intended to show the different levels of chemical complexities and it should be noted that the chemical kinetics of the reactions is also a major factor of the overall efficiency. This is also evident from the growth rate analysis (Figure 2), where the highest values are obtained for $\mathrm{SiHCl}_{3}$ and the lowest values comes with $\mathrm{SiH}_{4}+\mathrm{HCl}$ for all carbon precursors.

Initial decomposition products of propane are $\mathrm{CH}_{3}$ and $\mathrm{C}_{2} \mathrm{H}_{5} . \mathrm{CH}_{3}$ then reacts with $\mathrm{H}_{2}$ to become $\mathrm{CH}_{4}+\mathrm{H}$, while $\mathrm{C}_{2} \mathrm{H}_{5}$ sequentially will lose one hydrogen atom until it reaches $\mathrm{C}_{2} \mathrm{H}_{2} \cdot{ }^{12}$ Decomposition of $\mathrm{C}_{2} \mathrm{H}_{4}$ follows this second branch, producing almost exclusively

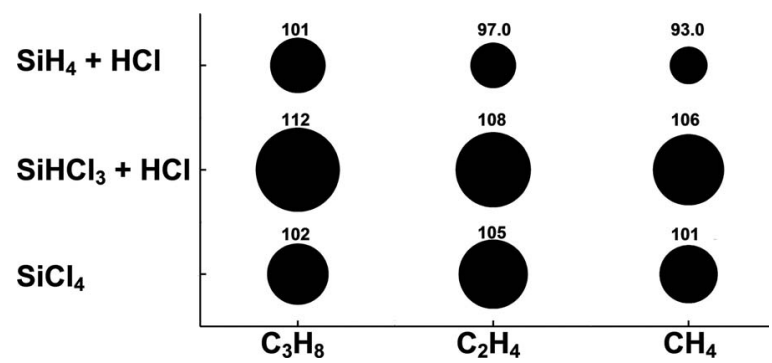

Figure 2. Growth rates in $\mu \mathrm{m} / \mathrm{h}$ for the precursor combinations studied. $\mathrm{C} / \mathrm{Si}$ was equal to 1 for all experiments. Circle diameter serve as a guide for the eye to show differences between the chemistries.

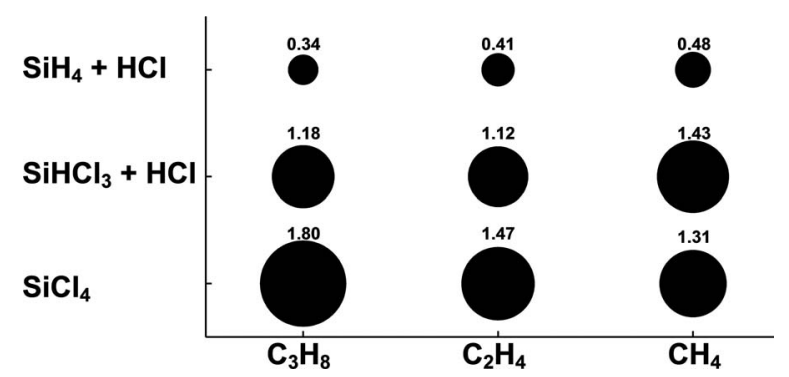

Figure 3. Surface roughness at $\mathrm{C} / \mathrm{Si}=0.9$ as quantified by the root mean square (RMS) value in $\mathrm{nm}$ for the height variations on the surface measured by AFM on $20 \times 20 \mu \mathrm{m}^{2}$. The thickness of the epitaxial layers was 23-28 $\mu \mathrm{m}$. Growth temperature was $1575^{\circ} \mathrm{C}$ for $\mathrm{SiH}_{4}+\mathrm{HCl}$ and $1625^{\circ} \mathrm{C}$ for chlorosilanes. Circle diameter serve as a guide for the eye to show differences between the chemistries.

$\mathrm{C}_{2} \mathrm{H}_{2}$ at the $\mathrm{SiC}$ growth temperature. ${ }^{12}$ When using $\mathrm{CH}_{4}$ as the carbon precursor, first some $\mathrm{CH}_{3}$ will be formed, which then can combine into $\mathrm{C}_{2} \mathrm{H}_{6}$. The $\mathrm{C}_{2} \mathrm{H}_{6}$ can lose one hydrogen atom to form $\mathrm{C}_{2} \mathrm{H}_{5}$, which will then proceed along the route described above to reach $\mathrm{C}_{2} \mathrm{H}_{2} .{ }^{12}$ However, this involves quite many reaction steps, and it is therefore a relatively inefficient way to get a "useful" hydrocarbon molecule. This is also evident from the analysis of growth rates (Figure 2), where $\mathrm{CH}_{4}$ is shown to be the least efficient carbon precursor regardless of which silicon precursor is used.

The difference in growth rate efficiency between $\mathrm{C}_{2} \mathrm{H}_{4}$ and $\mathrm{C}_{3} \mathrm{H}_{8}$, where the growth rate for $\mathrm{SiCl}_{4}$ is higher with $\mathrm{C}_{2} \mathrm{H}_{4}$ than with $\mathrm{C}_{3} \mathrm{H}_{8}$, while the opposite applies to $\mathrm{SiHCl}_{3}$ and $\mathrm{SiH}_{4}$, is less easily explained. It could be speculated that there are some important reactions taking place between silicon and carbon containing species, and that they are different for the different precursor combinations. For example reactions between $\mathrm{SiHCl}_{3}$ and $\mathrm{CH}_{3}$ could be more probable (have lower activation energies) than reactions between $\mathrm{SiCl}_{4}$ and $\mathrm{CH}_{3}$. However, such reactions have not been studied extensively in the literature, and it is therefore difficult to determine the exact mechanisms. We therefore suggest that formation of organosilicons, i.e. species with $\mathrm{Si}-\mathrm{C}$ bonds can form in the gas phase and play a small, but significant role in the $\mathrm{SiC}$ growth. For the combination of $\mathrm{SiHCl}_{3}$ and $\mathrm{C}_{3} \mathrm{H}_{8}$, methyltrichlorosilane ( $\mathrm{SiCl}_{3} \mathrm{CH}_{3}$, MTS) could form after formation of $\mathrm{CH}_{3}$, by breaking a $\mathrm{C}-\mathrm{C}$ bond in $\mathrm{C}_{3} \mathrm{H}_{8}$ and breaking of the $\mathrm{Si}-\mathrm{H}$ bond in $\mathrm{SiHCl}_{3}$. Formation of MTS from $\mathrm{SiCl}_{4}+\mathrm{C}_{3} \mathrm{H}_{8}$ should be less likely given the slower decomposition of $\mathrm{SiCl}_{4}$ to $\mathrm{SiCl}_{3}$ given the higher symmetry of $\mathrm{SiCl}_{4}$ compared to $\mathrm{SiHCl}_{3}$ and the stronger $\mathrm{Si}-\mathrm{Cl}$ bond compared to the $\mathrm{Si}-\mathrm{H}$ bond. MTS has previously been shown to be an excellent precursor for Cl-based CVD for $\mathrm{SiC}^{3}{ }^{3}$ and formation of MTS could explain the significantly higher growth rate for $\mathrm{SiHCl}_{3}+\mathrm{C}_{3} \mathrm{H}_{8}$ compared to $\mathrm{SiCl}_{4}+\mathrm{C}_{3} \mathrm{H}_{8}$.

The surface roughness for the different precursor combinations are given in Figure 3 where it can be seen that the precursor combination giving the smoothest surface is $\mathrm{SiH}_{4}+\mathrm{HCl}+\mathrm{C}_{3} \mathrm{H}_{8}$. It can also be noted that the surfaces with the lowest roughness are all grown by a growth chemistry based on $\mathrm{SiH}_{4}+\mathrm{HCl}$. It should be noted however that the comparison of surface roughness is not straight forward since the samples of different $\mathrm{Si}$ chemistries are not grown at the same temperature. The chlorosilanes render a rougher surface with $\mathrm{SiCl}_{4}$ giving slightly rougher surfaces than $\mathrm{SiHCl}_{3}$, except for when $\mathrm{CH}_{4}$ is used.

The surface morphology of the epitaxial layers grown by the precursor combinations at $\mathrm{C} / \mathrm{Si}=0.9$ are seen in the AFM images given in Figure 4. The high quality morphologies for the $\mathrm{SiH}_{4}+\mathrm{HCl}$ based chemistry suggested by the RMS values in Figure 3, are confirmed by the AFM images in Figure 4. The chlorosilanes gives step-bunched surfaces with surface defects on the step edges at $\mathrm{C} / \mathrm{Si}=0.9$. It should be noted that these surface defects are significantly smaller than the surface defects observed after growth with chlorosilanes at $1575^{\circ} \mathrm{C}$, as discussed above. The surface defects are most likely caused by $\mathrm{Si}$ droplets forming at the step edges and subsequently consumed during 


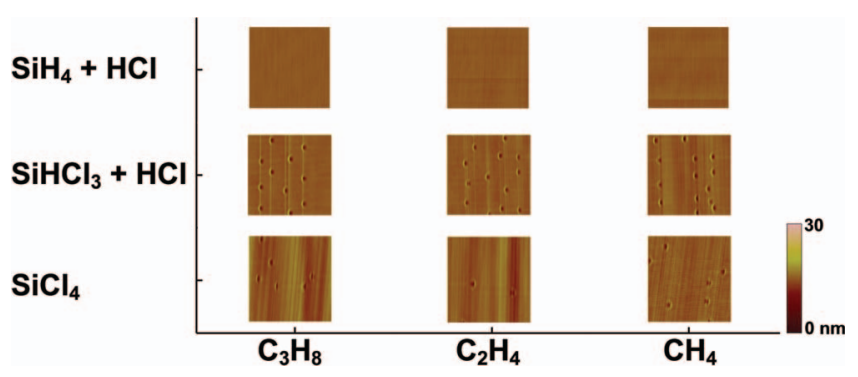

Figure 4. AFM images $\left(20 \times 20 \mu \mathrm{m}^{2}\right)$ for the precursor combinations with $\mathrm{C} / \mathrm{Si}=0.9$. RMS values for the images are given in Figure 3. Growth temperature was $1575^{\circ} \mathrm{C}$ for $\mathrm{SiH}_{4}+\mathrm{HCl}$ and $1625^{\circ} \mathrm{C}$ for chlorosilanes.

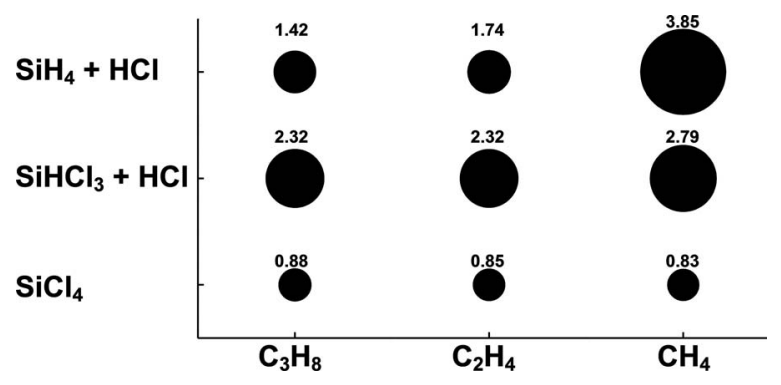

Figure 5. Surface roughness at $\mathrm{C} / \mathrm{Si}=0.6$ as quantified by the root mean square (RMS) value in $\mathrm{nm}$ for the height variations on the surface measured by AFM on $20 \times 20 \mu \mathrm{m}^{2}$. The thickness of the epitaxial layers was $16-21 \mu \mathrm{m}$. Growth temperature was $1575^{\circ} \mathrm{C}$ for $\mathrm{SiH}_{4}+\mathrm{HCl}$ and $1625^{\circ} \mathrm{C}$ for chlorosilanes. Circle diameter serve as a guide for the eye to show differences between the chemistries.

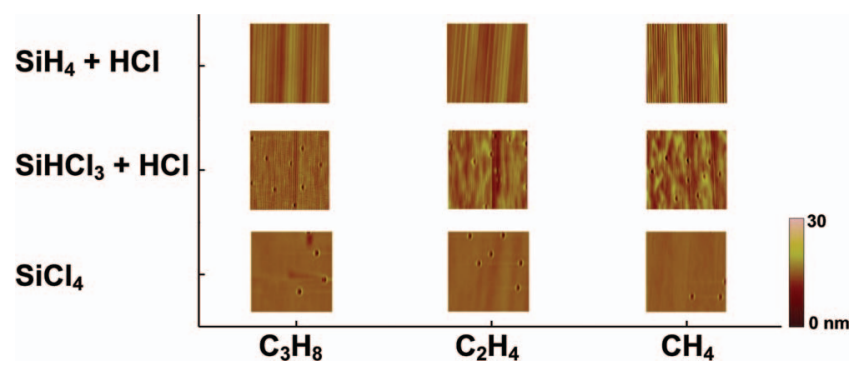

Figure 6. AFM images $\left(20 \times 20 \mu \mathrm{m}^{2}\right)$ for the precursor combinations with $\mathrm{C} / \mathrm{Si}=0.6$. RMS values for the images are given in Figure 5. Growth temperature was $1575^{\circ} \mathrm{C}$ for $\mathrm{SiH}_{4}+\mathrm{HCl}$ and $1625^{\circ} \mathrm{C}$ for chlorosilanes.

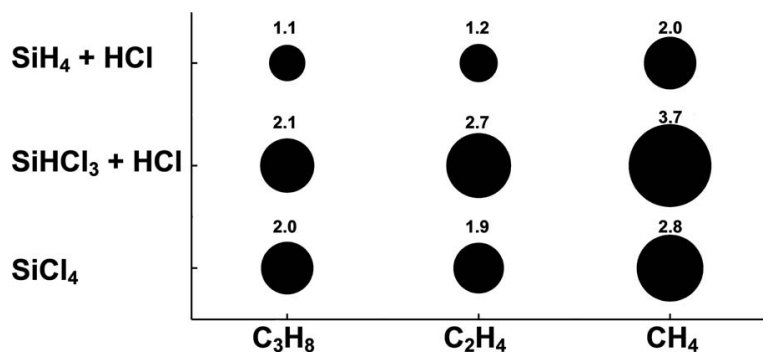

Figure 7. Net carrier concentration $\left(\mathrm{N}_{\mathrm{d}}-\mathrm{N}_{\mathrm{a}}\right)$ given in units of $10^{14} \mathrm{~cm}^{-3}$ for the unintentionally doped epitaxial layers grown by the different precursor combinations with $\mathrm{C} / \mathrm{Si}=1$. Circle diameter serve as a guide for the eye to show differences between the chemistries.

growth, leaving a surface defect on the $\mathrm{SiC}$ surface. This is further supported by the model that silicon species have a higher sticking coefficient on steps. ${ }^{13}$ Low temperature photoluminescence of the defects showed that they consisted of $4 \mathrm{H}-\mathrm{SiC}$ and the defects could be removed by increasing the $\mathrm{Cl} / \mathrm{Si}$ ratio from 4 to 5 . The highest density of surface defects is seen on the layers grown with $\mathrm{SiHCl}_{3}$ which can be explained by the higher growth rate for this silicon precursor.
The absence of defects on layers grown by $\mathrm{SiH}_{4}+\mathrm{HCl}$ could then be explained by the low growth rate. It could also be argued that the etching effect of $\mathrm{HCl}$ on the $\mathrm{SiC}$ surface is more pronounced in the $\mathrm{SiH}_{4}$ case, as compared to the case with $\mathrm{SiHCl}_{3}$. It should be noted that to reach the same $\mathrm{Cl} / \mathrm{Si}$ ratio, the flow of $\mathrm{HCl}$ was $500 \mathrm{~mL} / \mathrm{min}$ in the gas mixture for the $\mathrm{SiH}_{4}$-based process while it was $125 \mathrm{~mL} / \mathrm{min}$ for the $\mathrm{SiHCl}_{3}$-based process.

Interestingly, when going to carbon limited growth chemistry by adjusting the $\mathrm{C} / \mathrm{Si}$ ratio in the gas mixture to 0.6 , the situation is changed. As seen in Figure 5, $\mathrm{SiCl}_{4}$ based growth chemistry now gives the lowest RMS values and the combination of $\mathrm{SiCl}_{4}$ and $\mathrm{CH}_{4}$ gives the lowest RMS values. $\mathrm{SiHCl}_{3}$ gives rather high surface roughness also at $\mathrm{C} / \mathrm{Si}=0.6$, regardless of carbon precursor while $\mathrm{SiH}_{4}+\mathrm{HCl}$ yields more rough surfaces than $\mathrm{SiCl}_{4}$. A very high surface roughness is produced by the combination of $\mathrm{SiH}_{4}+\mathrm{HCl}$ and $\mathrm{CH}_{4}$, suggesting that these conditions are out of the narrow chemical window needed for deposition with this precursor combination. ${ }^{7}$

The AFM images for the precursor combinations at $\mathrm{C} / \mathrm{Si}=0.6$ are given in Figure 6. It can be seen that $\mathrm{SiH}_{4}+\mathrm{HCl}$ gives step bunched surfaces at this silicon rich condition, in line with previous findings. ${ }^{9}$ The step bunching is not as pronounced for $\mathrm{SiHCl}_{3}$ based chemistry and absent when using $\mathrm{SiCl}_{4}$, which is in line with our previous findings that $\mathrm{SiCl}_{4}$ gives the best morphology for silicon rich conditions. ${ }^{14}$

It should, however, be noted that the lowest RMS values obtained at $\mathrm{C} / \mathrm{Si}=0.6$ is higher than the lowest obtained for $\mathrm{C} / \mathrm{Si}=0.9$. An overall observation from both $\mathrm{C} / \mathrm{Si}$ ratios is that the surface roughness seems to depend on the silicon precursor chemistry rather than the carbon precursor chemistry. Except for $\mathrm{SiH}_{4}+\mathrm{HCl}$ which gives very rough morphology with $\mathrm{CH}_{4}$ at $\mathrm{C} / \mathrm{Si}=0.6$, which is in line with our previous findings. ${ }^{7}$ One could suggest that the lower surface roughness for $\mathrm{SiCl}_{4}$ is due to a lower growth rate in the carbon limited chemistry. But while the growth rate indeed drops $29 \%$, from around $105 \mu \mathrm{m} / \mathrm{h}$ at $\mathrm{C} / \mathrm{Si}=1$ to $75 \mu \mathrm{m}$ at $\mathrm{C} / \mathrm{Si}=0.6$ when using $\mathrm{SiCl}_{4}$, the growth rate for $\mathrm{SiHCl}_{3}$ drops $27 \%$, from 110 to $80 \mu \mathrm{m} / \mathrm{h}$ for $\mathrm{SiHCl}_{3}$, and the growth rate for $\mathrm{SiH}_{4}+\mathrm{HCl}$ drops $37 \%$, from 95 to $60 \mu \mathrm{m} / \mathrm{h}$ for $\mathrm{SiH}_{4}+\mathrm{HCl}$. The better morphology for $\mathrm{SiCl}_{4}$ at $\mathrm{C} / \mathrm{Si}=0.6$ should thus be an effect of the reactivity of the $\mathrm{SiCl}_{4}$ molecule. It can here be speculated that the reactivity of $\mathrm{SiCl}_{4}$ is well matched to the low $\mathrm{C} / \mathrm{Si}$ enabling formation of MTS to a higher degree than at higher $\mathrm{C} / \mathrm{Si}$ which gives a better morphology.

The net carrier concentration $\left(\mathrm{N}_{\mathrm{d}}-\mathrm{N}_{\mathrm{a}}\right)$ given by the background doping of the epitaxial layers grown from the different precursor chemistries are compared in Figure 7 . It can be seen that all layers have a background doping in the low $10^{14} \mathrm{~cm}^{-3}$ range and that the carbon precursor yielding the highest doping levels is $\mathrm{CH}_{4}$. Nitrogen incorporation has previously been shown to be independent of growth rate in chloride-based CVD of $\mathrm{SiC}^{15}$ so the higher doping for layers grown using $\mathrm{CH}_{4}$ is most likely due to different effective $\mathrm{C} / \mathrm{Si}$ ratios on the surface rather than an effect of growth rate. The doping levels in the epitaxial layers thus suggest that the carbon supply to the surface is less efficient when using $\mathrm{CH}_{4}$. It can also be noted that the somewhat higher doping levels in epitaxial layers grown using $\mathrm{CH}_{4}$ could be explained by a somewhat higher nitrogen content in $\mathrm{CH}_{4}$ compared to $\mathrm{C}_{2} \mathrm{H}_{4}$ and $\mathrm{C}_{3} \mathrm{H}_{8}$ in combination with the fact that one must use twice the flow of $\mathrm{CH}_{4}$ to get the same amount of carbon as for $\mathrm{C}_{2} \mathrm{H}_{4}$. The difference between the silicon precursors and propane and ethylene is only minor indicating robust growth chemistry with all precursor combinations except those with $\mathrm{CH}_{4}$.

\section{Concluding Remarks}

If the prime interest is to grow thick layers in short amount of time, the chlorinated silanes $\mathrm{SiCl}_{4}$ and especially $\mathrm{SiHCl}_{3}$ are better than a combination of natural silane and $\mathrm{HCl}$. This can be understood when considering the number of reaction steps in the gas phase chemical reaction mechanisms for producing $\mathrm{SiCl}_{2}$, which is the most important $\mathrm{Si}$ species. As carbon precursor, $\mathrm{C}_{3} \mathrm{H}_{8}$ or $\mathrm{C}_{2} \mathrm{H}_{4}$ are more or less equal in performance with a slight advantage for $\mathrm{C}_{3} \mathrm{H}_{8}, \mathrm{CH}_{4}$ is however not 
a carbon precursor that should be used unless extraordinary growth conditions are needed.

If the prime interest is perfect morphology, our results show that $\mathrm{SiH}_{4}+\mathrm{HCl}$ should be the best chlorinated route at $\mathrm{C} / \mathrm{Si}$ around 1 . It should here be remembered that experiments with $\mathrm{SiH}_{4}+\mathrm{HCl}$ were done at slightly lower temperature in our study. If growth at low $\mathrm{C} / \mathrm{Si}$ is needed, $\mathrm{SiCl}_{4}$ gives the best morphology. Our study shows no effect on doping incorporation with precursor chemistry.

We suggest that formation of organosilicons can explain parts of our results and that more advanced SiC CVD modeling, taking into account formations of species with $\mathrm{Si}-\mathrm{C}$ bonds, should be done to further study this.

Finally we note that kinetics in the CVD process should have an effect on the growth and that the reactor design will most likely affect the kinetics in the deposition.

\section{Acknowledgment}

Ivan Ivanov is gratefully acknowledged for LTPL measurements. Authors gratefully acknowledge the financial support from Swedish Energy Agency, Swedish Foundation for Strategic research (SSF), and the Swedish Research Council (VR).

\section{References}

1. H. Pedersen, S. Leone, O. Kordina, A. Henry, S. Nishizawa, Y. Koshka, and E. Janzén, Chem. Rev., 112, 2434 (2012)

2. G. Aylward and T. Findlay, SI Chemical Data 4th ed., p 115, John Wiley\& Sons, Australia, (1998).

3. H. Pedersen, S. Leone, A. Henry, F. C. Beyer, V. Darakchieva, and E. Janzén, $J$. Cryst. Growth, 307, 334 (2007).

4. D. J. Larkin, phys. stat. sol. B, 202, 305 (1997)

5. A. Fiorucci, D. Moscatelli, and M. Masi, Surf. Coat. Technol. 201, 8825 (2007).

6. H. Pedersen, S. Leone, A. Henry, A. Lundskog, and E. Janzén, phys. stat. sol. RRL 2, 278 (2008)

7. M. Yazdanfar, H. Pedersen, P. Sukkaew, Ö. Danielsson, O. Kordina, and E. Janzén, J. Crystal Growth, 390, 24 (2014).

8. A. Henry, J. Hassan, J. P. Bergman, C. Hallin, and E. Janzén, Chem. Vapor Deposition, 12, 475 (2006).

9. M. Yazdanfar, I. G. Ivanov, H. Pedersen, O. Kordina, and E. Janzén, J. Appl. Phys., 113, 223502 (2013)

10. M. D. Allendorf and R. J. Kee, J. Electrochem. Soc., 138, 841 (1991)

11. C. Cavallotti, F. Rossi, S. Ravasio, and M. Masi, Ind. Eng. Chem. Res., 53, 9076 (2014).

12. Ö. Danielsson, P. Sukkaew, L. Ojamäe, O. Kordina, and E. Janzén, Theo. Chem. Acc., 132, 1398 (2013).

13. T. Kimoto and H. Matsunami, J. Appl. Phys., 75, 850 (1994).

14. M. Yazdanfar, P. Stenberg, I. D. Booker, I. G. Ivanov, O. Kordina, H. Pedersen, and E. Janzén, J. Cryst. Growth 380, 55 (2013).

15. H. Pedersen, F. C. Beyer, J. Hassan, A. Henry, and E. Janzén, J. Cryst. Growth, 311, $1321(2009)$ 